Article

\title{
Kinase-Based Screening of Marine Natural Extracts Leads to the Identification of a Cytotoxic High Molecular Weight Metabolite from the Mediterranean Sponge Crambe tailliezi
}

\author{
Thi-Ngoc-Dung Nguyen ${ }^{1,2}$, Omid Feizbakhsh ${ }^{1}$, Estelle Sfecci ${ }^{3}$, Blandine Baratte ${ }^{1,4}$, \\ Claire Delehouzé ${ }^{1,5}$, Adrien Garcia ${ }^{3}$, Corentin Moulin ${ }^{3}$, Pierre Colas ${ }^{1}$, Sandrine Ruchaud ${ }^{1, *}$, \\ Mohamed Mehiri ${ }^{3, *}$ and Stéphane Bach $1,4, *$ \\ 1 Integrative Biology of Marine Models Laboratory (LBI2M), Sorbonne Université, CNRS, UMR 8227, Station \\ Biologique de Roscoff, CS 90074, 29688 Roscoff Cedex, France; dnguyenthingoc@sb-roscoff.fr (T.-N.-D.N.); \\ omid.feizbakhsh@sb-roscoff.fr (O.F.); blandine.baratte@sb-roscoff.fr (B.B.); \\ claire.delehouze@seabelife.com (C.D.); colas@sb-roscoff.fr (P.C.) \\ 2 Department of Chemical Analysis and Drug Quality Control, Faculty of Pharmacy, \\ University of Medicine and Pharmacy, Ho Chi Minh City 70000, Vietnam \\ 3 Marine Natural Products Team, Université Côte d'Azur, CNRS, Institut de Chimie de Nice, UMR 7272, \\ 06108 Nice, France; estelle.sfecci@univ-cotedazur.fr (E.S.); adrien.garcia@univ-cotedazur.fr (A.G.); \\ corentin.moulin@univ-cotedazur.fr (C.M.) \\ 4 Sorbonne Université, CNRS, Station Biologique de Roscoff, FR 2424, Plateforme de criblage KISSf (Kinase \\ Inhibitor Specialized Screening facility), Place Georges Teissier, 29682 Roscoff, France \\ 5 SeaBeLife Biotech, Place Georges Teissier, 29682 Roscoff, France \\ * Correspondence: sandrine.ruchaud@sb-roscoff.fr (S.R.); mohamed.mehiri@univ-cotedazur.fr (M.M.); \\ bach@sb-roscoff.fr (S.B.); Tel.: +33-298-292-309 (S.R.); +33-492-076-154 (M.M.); +33-298-292-391 (S.B.); \\ Fax: +33-492-076-151 (M.M.); +33-298-292-526 (S.R. \& S.B.)
}

Received: 6 September 2019; Accepted: 7 October 2019; Published: 9 October 2019

\begin{abstract}
Regulated cell death (RCD) results from the activation of one or more signal transduction modules both in physiological or pathological conditions. It is now established that RCD is involved in numerous human diseases, including cancer. As regulated cell death processes can be modulated by pharmacological tools, the research reported here aims to characterize new marine compounds acting as RCD modulators. Protein kinases (PKs) are key signaling actors in various RCDs notably through the control of either mitosis (e.g., the PKs Aurora A and B) or necroptosis (e.g., RIPK1 and RIPK3). From the primary screening of 27 various extracts of marine organisms collected in the Mediterranean Sea, an extract and subsequently a purified high molecular weight compound dubbed P3, were isolated from the marine sponge Crambe tailliezi and characterized as a selective inhibitor of PKs Aurora A and B. Furthermore, P3 was shown to induce apoptosis and to decrease proliferation and mitotic index of human osteosarcoma U-2 OS cells.
\end{abstract}

Keywords: Screening; kinase inhibition; regulated cell death; RIP1-independent cell death; marine natural products; Crambe tailliezi

\section{Introduction}

"Live or die" is the binary choice that a cell has to make in order to maintain the balance in the functions of a multicellular organism (also known as the homeostasis). Thus, similarly to the control of cell division, cell death is also tightly regulated [1]. The concept of "programmed cell death (PCD)", which first appeared in the early 1960s, designates the natural process of regulated cell death that 
occurs during organisms' development and tissue homeostasis [2,3]. PCD is now considered as a particular form of "regulated cell death" (RCD) that occurs in strictly physiological scenarios [4]. Death signaling pathways can be activated by internal or external signals. It is a natural process to eliminate undesirable cells including tumor ones. Thus, RCD plays a crucial role in either physiological or pathological conditions. Abnormal RCD can cause disorders such as cancer, inflammatory diseases, and neurodegenerative diseases [1,5]. Apoptosis was the first RCD described (1972) [6] and the most studied until now. The classical apoptosis pathway is triggered and mediated by cysteine-aspartic proteases called caspases [7]. The main goal in cancer chemotherapy is to induce apoptosis but many cancer cells gain the ability to overcome RCD by mutations giving them a survival advantage. Therefore, there is an urgent need for new therapeutic strategies based on new potent anticancer molecules activating canonical and noncanonical cell-death subroutines [8]. Indeed, recently, several groups have discovered and described other types of RCD that can be targeted, like necroptosis, autophagy, ferroptosis, or death by mitotic catastrophe [4,9]. These alternative RCD pathways may represent opportunities to trigger cell death when facing apoptosis resistance [10]. However, various open questions need to be addressed regarding their controls and regulatory crosstalk. Therefore, the characterization of new chemical triggers of RCD can kill two birds with one stone: (i) deciphering the molecular mechanisms leading to cell death and (ii) characterizing new putative drugs for cancer therapy.

The great potential of marine products for human therapy was discovered in the 1950s with the discovery of two nucleosides spongothymidine and sponguridine from the Caribbean sponge Cryptotethia crypta [11-13]. Nowadays, it is well known that marine organisms can be new sources of drugs modulating various RCD processes [14]. Marine sponges (and their associated microbiota) are among the most promising group because of the chemical diversity of their secondary metabolites and their strong bioactivity as cytotoxic agents or protein kinase inhibitors (PKIs), among other activities [15-17]. Protein kinases are involved in the regulation of numerous cellular processes, often in response to an external stimulus. This family of enzymes has become one of the most important suppliers of drug targets and perhaps up to one third of drug discovery efforts worldwide are focused on the discovery of new PKIs [18]. The number of approved PKIs continues to grow and as of August 2019, 50 drugs have reached the US market (Figure 1), 85\% of which are used for the treatment of malignancies [18]. More than 200 orally effective PKIs are currently in clinical trials worldwide (a complete and updated listing of PKIs in clinical trials can be found at www.icoa.fr/pkidb/) $[19,20]$.

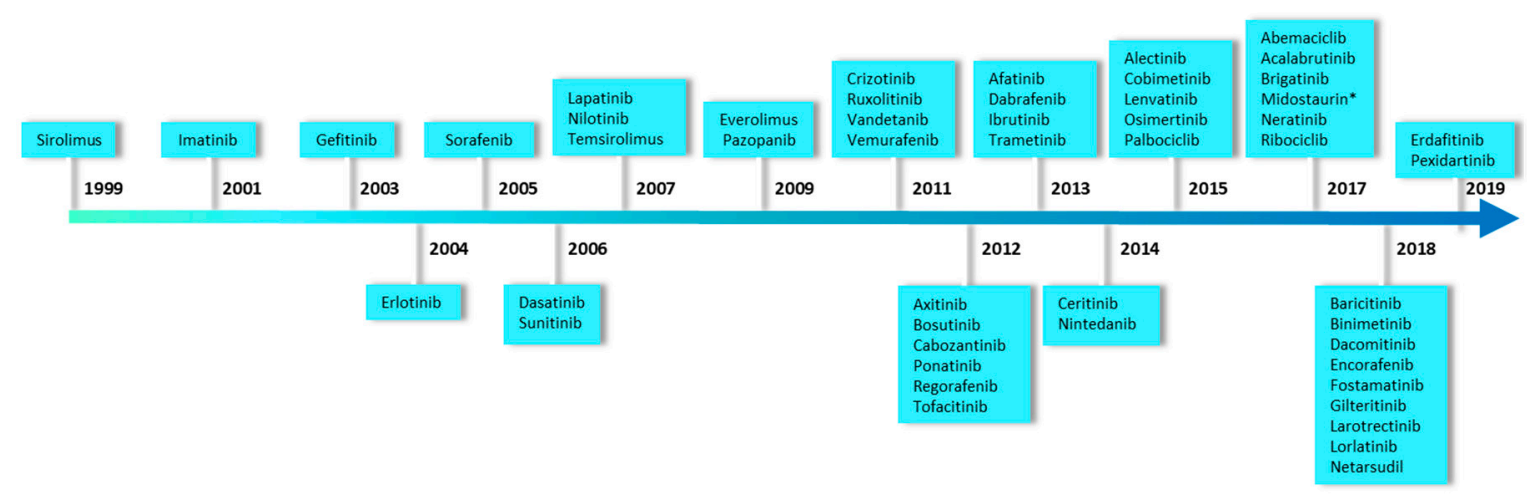

Figure 1. Food and Drug Administration (FDA)-approved protein kinase inhibitors as of August 2019. This timeline was performed using the data reported in Roskoski R., 2019. * Midostaurin is a derivative of a marine natural compound.

Manning et al. have first catalogued the $518+$ protein kinases encoded by the human genome (the "kinome"). The kinome was classified based on protein sequences into eight typical groups (AGC, CAMK, CK1, CMGC, STE, TK, TKL, and other, see the legend of Figure 2 for details) and 13 atypical families [21]. 
A) Primary screening (extracts tested at $50 \mu \mathrm{g} / \mathrm{mL}$ )
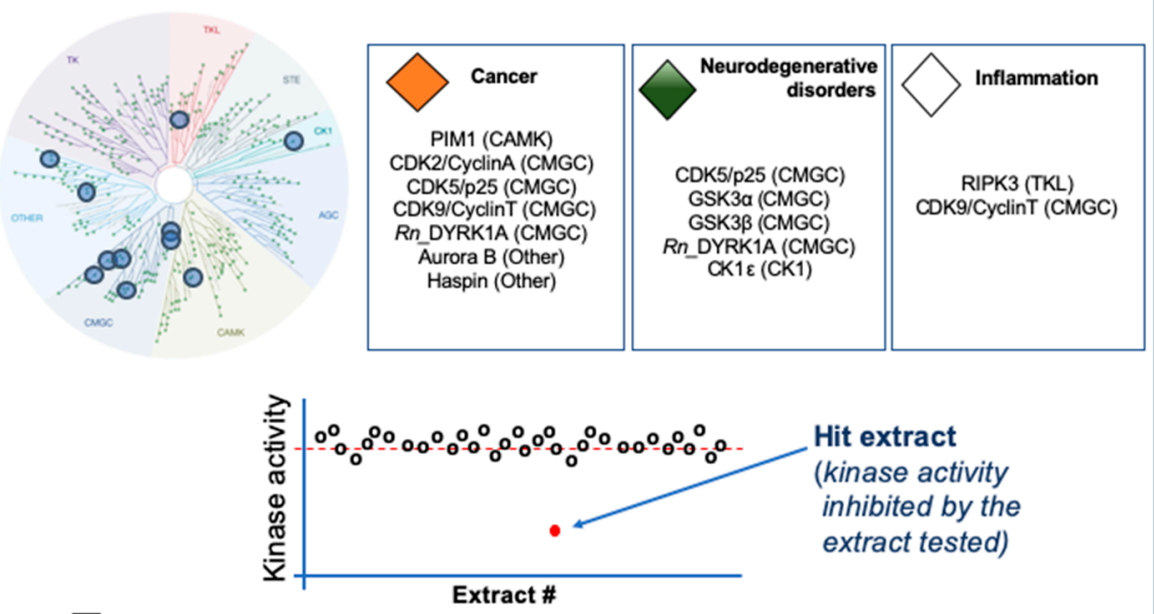

$\sqrt{5}$

B) Hit validation:

Determination of the $\mathrm{IC}_{50}$ value
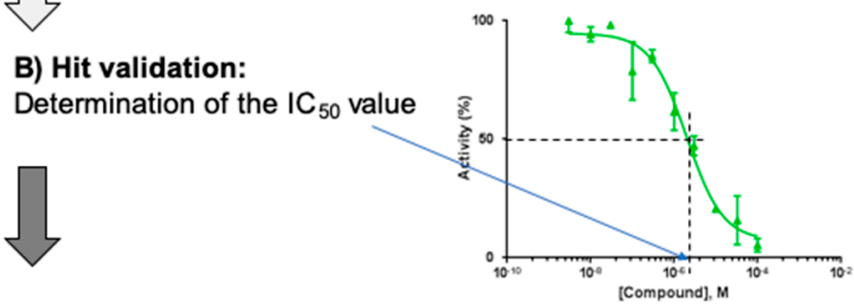

C) Bioguided purification of the bioactive natural product from the extract

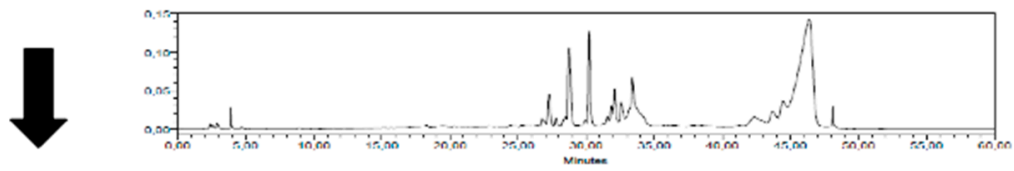

D) Identification of the therapeutic field targeted by the extracts
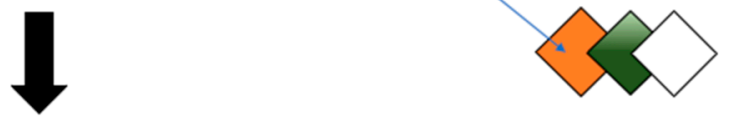

E) Study of the cellular effect focused on the therapeutic field

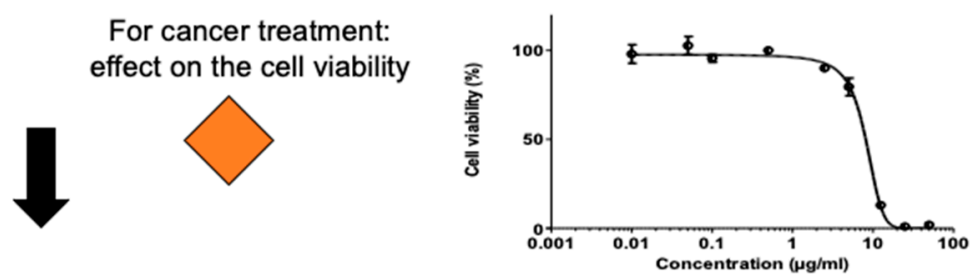

F) Study of the mechanism of action (MoA) of the purified natural product 
Figure 2. Workflow of the kinase-based screening assay of the marine extracts. (A) During the first step, a primary screening is performed against a disease-related panel of protein kinases. These targets are selected among the human kinome as mentioned on the figure by blue dots on the circular tree. This image was generated using TREEspot ${ }^{\mathrm{TM}}$ Software Tool (Eurofins DiscoverX Corporation, Fremont, CA, USA) and reprinted with permission from KINOMEscan ${ }^{\circledR}$, a division of Eurofins DiscoverX Corporation (C DISCOVERX CORPORATION 2010). The codes reported on this figure indicate the subclasses of protein kinases: CMGC for CDKs, MAP kinases, GSK, and CDK-like kinases; AGC for protein Kinase A, C, and G families (PKA, PKC, PKG); CAMK for Ca2+/calmodulin-dependent protein kinases; CK1, Cell/Casein Kinase 1; STE, STE Kinases (Homologs of yeast STErile kinases); TKL, Tyrosine Kinases-Like; TK, Tyrosine Kinases. All protein kinases used here are human unless specified $R n$, Rattus norvegicus. As mentioned on this theoretical scatter plot, an extract is selected as screening hit when it is shown to inhibit the kinase activity of the tested kinase. (B) In a second step, the $\mathrm{IC}_{50}$ values were then calculated from dose-response curves in order to validate the first hits. (C) Kinase inhibition was then used to guide the purification of the natural products from the crude extracts. From this step, the identification of the inhibited kinase drives the selection of both the therapeutic field (D) and the study of the cellular effects of the tested natural product (E). Here is shown the study of a compound that can inhibit kinase(s) involved in cancer (e.g., Aurora B kinase). The phenotype studied is the "dose-dependent modulation of the cellular viability by the natural product". (F) In an optimal case, the final step is the study of the mechanism of action and, if possible, the characterization of the cellular targets of the selected marine products.

In keeping with the high chemodiversity of PKIs described in marine sponges [15], a panel of 11 protein kinases was used as a filtering technique to associate a marine natural product with a disease-related cellular phenotype. Following this primary enzymatic screening campaign of an original collection of 27 extracts from marine organisms collected in the Mediterranean Sea, an extract from Crambe tailliezi and one of its purified product (P3) were shown to inhibit Aurora A and B kinases. This result oriented the analysis on the cellular phenotype induced by P3. The results obtained indicated that P3 could induce the programmed cell death of human cancer cell lines derived from leukemia and solid tumors affecting breast, colorectal, liver, bone, pancreas, and brain tissues. Moreover, the treatment of osteosarcoma U-2 OS cell line with P3 triggered apoptotic cell death.

\section{Results}

The methodological workflow used to characterize new bioactive extracts and purified fractions from a set of selected marine organisms is schematically represented in Figure 2. The primary screening was performed on a panel of defined targets (kinases), an approach often referred to as reverse chemical genetics/biology. Note here that the so-called forward chemical genetics/biology approaches entail phenotypic screening (e.g., used in neuropsychiatric drug discovery [22]).

\subsection{Primary Screening of a Selected Set of Purified Marine Extracts Against a Panel of Disease-Related Kinases}

The inhibitory activity of 27 extracts of marine organisms collected in the Mediterranean Sea (see the Materials and Methods section for details on the protocol used to obtain the extracts) was screened against a panel of 11 disease-related protein kinases (listed on Figure 2): Aurora B, CDK2/CyclinA, CDK5/p25, CDK9/CyclinT, CK1ع, GSK3 $\alpha$, GSK3 $\beta$, Haspin, Pim1, RIPK3 kinases, and rat DYRK1A. The results obtained are reported in Table 1. 
Table 1. Target-based screening of extracts from various marine organisms from Mediterranean Sea. Characterization of extracts with kinase inhibitory activity.

\begin{tabular}{|c|c|c|c|c|c|c|c|c|c|c|c|c|}
\hline Extract & Marine organism & Hs_CDK2/CyclinA & Hs_CDK5/p25 & Hs_CDK9/CyclinT & Hs_Haspin & Hs_PIM1 & Rn_DYRK1A & Hs_CK1 $1 \varepsilon$ & Hs_GSK3 $\alpha$ & Hs_GSK3 $\beta$ & Hs_RIPK3 & Hs_AuroraB \\
\hline E1 & Ascidium Aplidium sp. & 81 & $\geq 100$ & 100 & 63 & $\geq 100$ & 97 & 94 & $\geq 100$ & 76 & 87 & 99 \\
\hline E2 & $\begin{array}{l}\text { Ascidium Cystodytes } \\
\text { sp. }\end{array}$ & 68 & 58 & 52 & 25 & 62 & 29 & 89 & 54 & 70 & 77 & 83 \\
\hline E3 & $\begin{array}{l}\text { Ascidium Halocynthia } \\
\text { papillosa }\end{array}$ & 85 & 73 & 81 & 65 & 90 & 95 & $\geq 100$ & 91 & 97 & 91 & 100 \\
\hline E4 & $\begin{array}{l}\text { Ascidium } \\
\text { Polysyncraton sp. }\end{array}$ & 69 & 82 & $\geq 100$ & 94 & 92 & $\geq 100$ & $\geq 100$ & $\geq 100$ & 88 & 86 & 90 \\
\hline E5 & Sponge Acanthella acuta & 100 & $\geq 100$ & 83 & 86 & $\geq 100$ & 87 & 78 & $\geq 100$ & 69 & $\geq 100$ & $\geq 100$ \\
\hline E6 & Sponge Agelas oroides & 71 & 74 & 46 & 26 & 67 & 19 & 46 & 23 & 35 & 80 & 69 \\
\hline E7 & $\begin{array}{l}\text { Sponge Axinella } \\
\text { polypoides }\end{array}$ & $\geq 100$ & $\geq 100$ & 87 & 84 & $\geq 100$ & 81 & 77 & $\geq 100$ & 67 & $\geq 100$ & $\geq 100$ \\
\hline E8 & Sponge Axinella sp. & 98 & $\geq 100$ & 91 & 93 & 87 & 63 & 82 & 68 & 71 & 87 & $\geq 100$ \\
\hline E9 & Sponge Axinyssa sp. & 71 & 63 & 80 & 96 & $\geq 100$ & 51 & $\geq 100$ & 96 & 88 & 96 & 83 \\
\hline E10 & Sponge Cacospongia sp. & $\geq 100$ & $\geq 100$ & 71 & 79 & 100 & $\geq 100$ & 92 & 88 & 68 & 93 & 96 \\
\hline E11 & Sponge Cliona viridis & 64 & $\geq 100$ & 94 & $\geq 100$ & $\geq 100$ & 85 & 98 & 100 & 85 & 95 & 100 \\
\hline E12 & Sponge Crambe crambe & 66 & 62 & 47 & $\geq 100$ & 16 & 37 & 19 & 84 & $\geq 100$ & $\geq 100$ & 79 \\
\hline E13 & Sponge Crambe tailliezi & 77 & 57 & 48 & 78 & 54 & 27 & 22 & 21 & 28 & 87 & 8 \\
\hline E14 & $\begin{array}{l}\text { Sponge Haliclona } \\
\text { mediterranea }\end{array}$ & 91 & $\geq 100$ & 89 & 87 & $\geq 100$ & 61 & 96 & 84 & $\geq 100$ & 97 & 100 \\
\hline E15 & $\begin{array}{l}\text { Sponge Hemimycale } \\
\text { columella }\end{array}$ & $\geq 100$ & $\geq 100$ & $\geq 100$ & 84 & $\geq 100$ & 100 & $\geq 100$ & 92 & 62 & 91 & 94 \\
\hline E16 & Sponge Hexadella sp. & 98 & 65 & 7 & 17 & 63 & 4 & 2 & 2 & 10 & 65 & 61 \\
\hline E17 & Sponge Ircinia oros & 40 & $\geq 100$ & 30 & 34 & $\geq 100$ & 26 & 17 & 13 & 9 & 72 & 91 \\
\hline E18 & Sponge Ircinia variabilis & 100 & 92 & 58 & 42 & 75 & 50 & $\geq 100$ & 41 & 37 & 88 & 94 \\
\hline E19 & Sponge Oscarella sp. & 66 & $\geq 100$ & 96 & 89 & 92 & $\geq 100$ & $\geq 100$ & $\geq 100$ & $\geq 100$ & 97 & 98 \\
\hline E20 & Sponge Phorbas topsenti & $\geq 100$ & $\geq 100$ & 91 & 77 & $\geq 100$ & 75 & 88 & 93 & 69 & 98 & $\geq 100$ \\
\hline E21 & $\begin{array}{l}\text { Sponge Pleraplesila } \\
\text { spinifera }\end{array}$ & $\geq 100$ & $\geq 100$ & 78 & 79 & $\geq 100$ & $\geq 100$ & $\geq 100$ & 98 & 54 & 90 & 87 \\
\hline E22 & $\begin{array}{l}\text { Sponge Pseudaxinyssa } \\
\text { sp. }\end{array}$ & 96 & $\geq 100$ & 31 & 12 & $\geq 100$ & 35 & 1 & 5 & 25 & 84 & $\geq 100$ \\
\hline E23 & Sponge Reniera fulva & 65 & $\geq 100$ & $\geq 100$ & 61 & $\geq 100$ & 83 & $\geq 100$ & 100 & 58 & $\geq 100$ & 99 \\
\hline E24 & Sponge Reniera mucosa & 88 & 86 & 28 & 25 & 96 & 50 & 17 & 14 & 45 & 64 & 43 \\
\hline E25 & Sponge Reniera sarai & $\geq 100$ & 76 & 36 & 11 & 50 & 42 & 42 & 28 & 51 & 86 & 86 \\
\hline E26 & $\begin{array}{l}\text { Sponge Sarcotragus } \\
\text { foetidus }\end{array}$ & 60 & $\geq 100$ & 66 & 14 & 79 & 29 & 21 & 13 & 4 & 92 & 97 \\
\hline E27 & $\begin{array}{l}\text { Sponge Sarcotragus } \\
\text { spinosulus }\end{array}$ & 65 & $\geq 100$ & 62 & 35 & 40 & 6 & 7 & 8 & 12 & 86 & 91 \\
\hline
\end{tabular}

Kinase activities in the presence of extracts $(50 \mu \mathrm{g} / \mathrm{mL})$ were measured by ADP-Glo luminescent assay (Promega, Madison, WI, USA), using $10 \mu \mathrm{M}$ ATP. Data are mean $(n=2)$ expressed in \% of maximal activity, compared with a DMSO control. The red color scale is used to highlight the values that are below $50 \%$ of residual kinase activity. CDK: cyclin-dependent kinase, Haspin: haploid germ cell-specific nuclear protein kinase, PIM: proto-oncogene proviral integration site for moloney murine leukemia virus, DYRK1A: dual specificity tyrosine phosphorylation regulated kinase 1A, CK1: casein kinase 1, GSK3: glycogen synthase kinase 3, RIPK: receptor-interacting protein kinase. Kinases are from human origin, Hs, Homo sapiens, unless specified Rn, Rattus norvegicus. 
The screen revealed that several extracts from Crambe tailliezi, Hexadella sp., Pseudaxinyssa sp., Ircinia oros, Sarcotragus foetidus, and Sarcotragus spinosulus showed interesting kinase inhibitory properties. The hit score obtained was very high: $50 \%$ calculated from the number of extracts inhibiting at least one kinase. Four ascidium extracts tested here (Aplidium sp., Cystodytes sp., Halocynthia papillosa and Polysyncraton sp.) did not show as much activity towards kinases as sponge extracts. As shown here, GSK3 isoforms $\alpha$ and $\beta$ were the most frequently targeted kinases.

The extract E13 from Crambe tailliezi inhibited the mitotic kinase Aurora B whereas the extract E12 from Crambe crambe, which is also a member of the Crambeidea family, did not. In regard to the rather good selectivity toward the kinase tested, Crambe tailliezi was selected for further fractionation and isolation of the active natural products. Indeed, within the Crambeidea family, Crambe tailliezi [23], an encrusting marine sponge also distributed in the Mediterranean Sea, is only poorly studied for either its chemical composition or its biological effects, contrary to Crambe crambe [24] that has been widely explored chemically since the 90s [25-28].

\subsection{P3, a High Molecular Weight Natural Product Isolated from Crambe tailliezi Sponge, Selectively Inhibits} Protein Kinases Aurora A and Aurora B

As the dichloromethane-methanol extract E13 from Crambe tailliezi was shown to inhibit few protein kinases from the panel tested, this crude organic extract was selected to isolate the active compound. The marine natural product P3 was thus found as the main component of the extract (see the materials and methods section for details and Figure S1).

The chemical structure of $\mathrm{P} 3$ compound was studied by positive-ion reflectron MALDI-TOF MS analysis (Figure 3) and NMR (Figure 4). Unfortunately, we were unable at this point to determine the chemical structure of P3 compound. The complexity of its structure is highlighted by its estimated molecular size (2200-2800 Da) as shown on Figure 3.

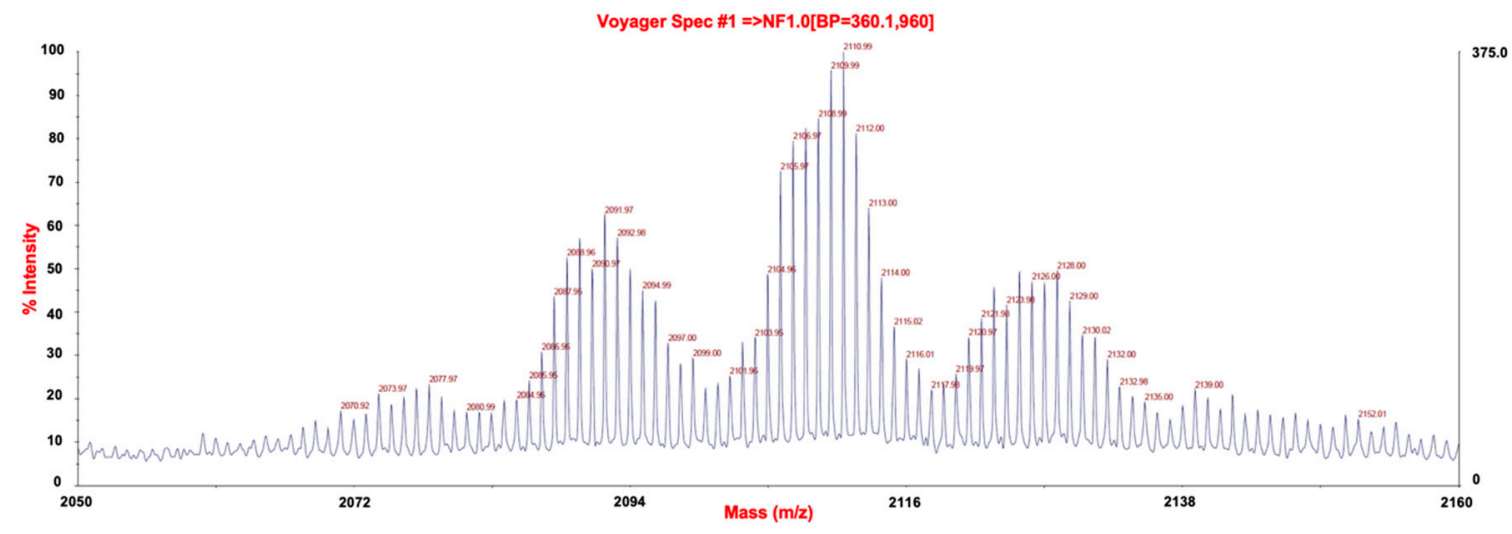

Figure 3. MALDI-TOF analysis of P3 (reflectron positive ion mode, DHB matrix).

NMR spectra of P3 contain several signals suggestive of a batzelladine-like metabolite [28] (Figure 4). In particular, signals at $\delta_{\mathrm{H}} 4.6-4.1 \mathrm{ppm}(\mathrm{H}-6), 3.8 \mathrm{ppm}(\mathrm{H} 8 \mathrm{a}), 3.6 \mathrm{ppm}(\mathrm{H} 7)$ in the ${ }^{1} \mathrm{H}$ NMR spectrum (Figure $4 \mathrm{~A}$ ) and the signal at $\delta_{\mathrm{c}} 52.0$ (C7) in the ${ }^{13} \mathrm{C}$ NMR spectrum (Figure $4 \mathrm{~B}$ ) are characteristic of a batzelladine $C$ nucleus [29].

The kinase inhibition properties of the purified product were evaluated. As shown in Table 2, P3 inhibited the kinase activity of Aurora B in a dose-dependent manner with a half-maximal inhibitory concentration $\left(\mathrm{IC}_{50}\right)$ of $2.63 \mu \mathrm{g} / \mathrm{mL}$. The activity of the extracts $\mathrm{E} 13$ and purified product were then tested on Aurora A, a closely related Aurora B kinase, also essential to mitosis. Both the extracts E13 and $\mathrm{P} 3$ showed an inhibitory activity on Aurora A, with $\mathrm{IC}_{50}$ values of 14.7 and $7.58 \mu \mathrm{g} / \mathrm{mL}$ respectively, in a concentration range close to the one obtained against Aurora B. In comparison with the extract E13, the purified compound showed greater inhibitory activity on both kinases Aurora A and Aurora 
B (Table 2 and Figure S2), which strongly suggests that P3 is the main if not sole molecule that accounts for the inhibitory activity of E13.

A

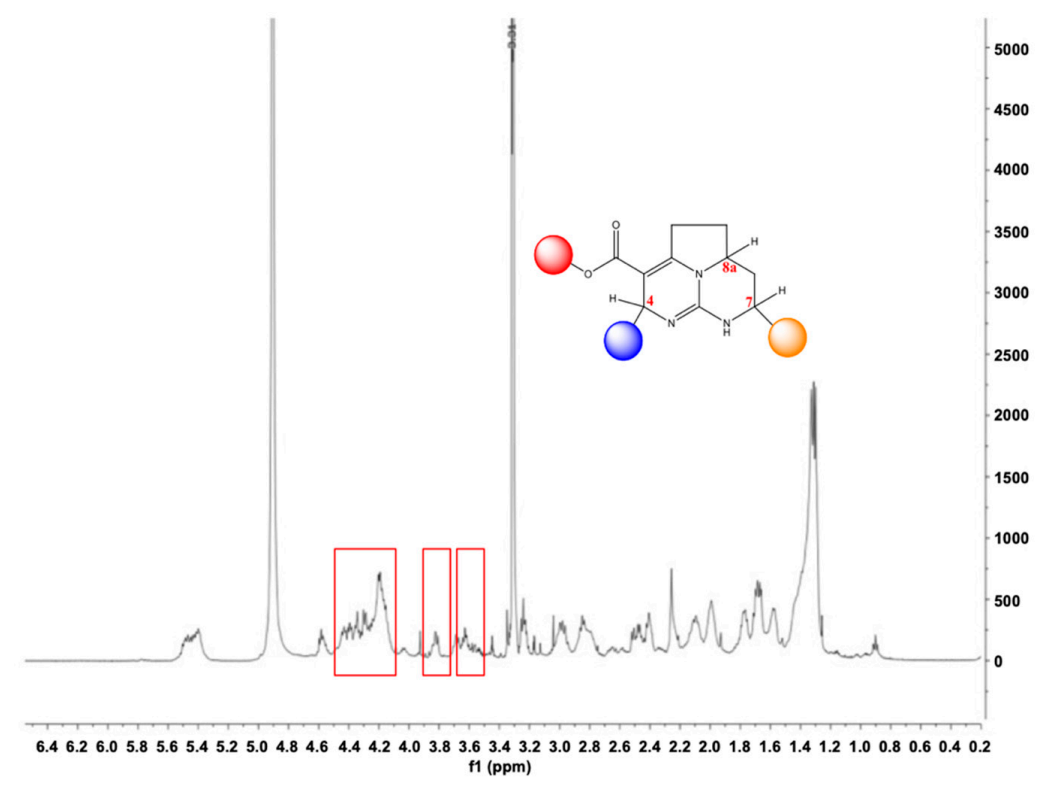

B

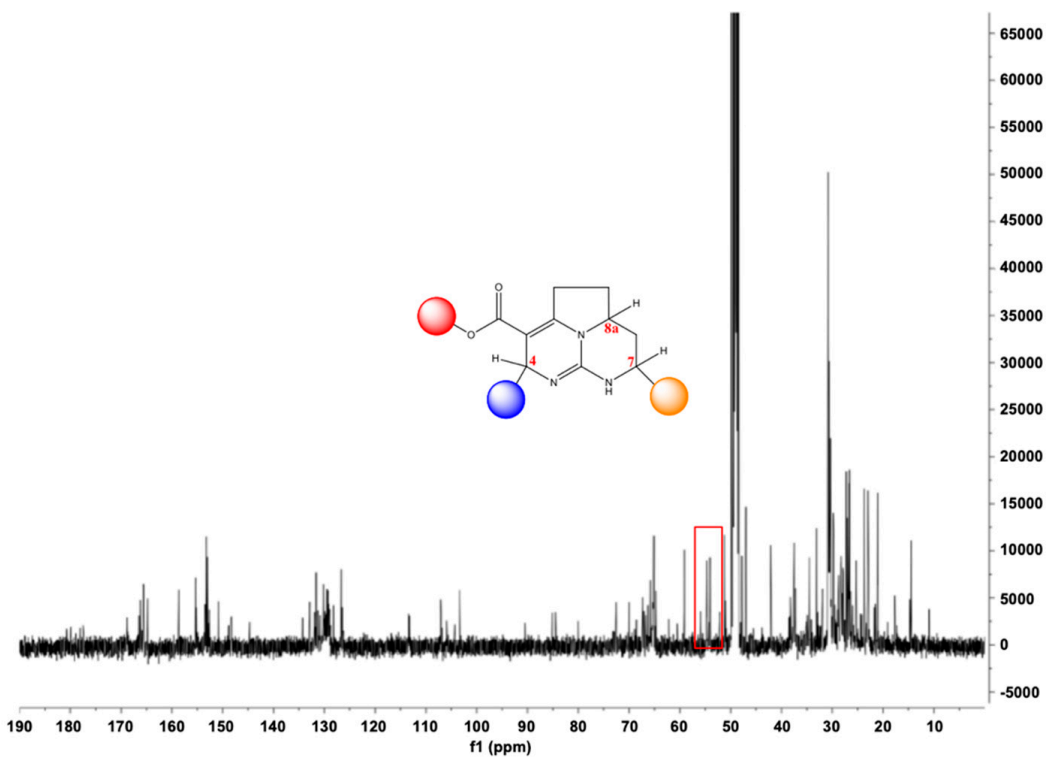

Figure 4. (A) ${ }^{1} \mathrm{H}$ NMR spectrum of $\mathrm{P} 3\left(\mathrm{CD}_{3} \mathrm{OD}, 500 \mathrm{MHz}\right) ;(\mathbf{B}){ }^{13} \mathrm{C}$ NMR spectrum of $\mathrm{P} 3\left(\mathrm{CD}_{3} \mathrm{OD}\right.$, $125 \mathrm{MHz})$.

Table 2. $\mathrm{IC}_{50}$ values obtained for $\mathrm{P} 3$ natural product from the kinase inhibition assay.

\begin{tabular}{cccc}
\hline \multirow{2}{*}{ Extract/Compound } & \multirow{2}{*}{ Marine organism } & \multicolumn{2}{c}{ IC $_{\mathbf{5 0}}(\boldsymbol{\mu g} / \mathrm{mL})$} \\
& & Aurora A & Aurora B \\
\hline E12 & Sponge Crambe crambe & N/A & 124.9 \\
E13 & Sponge Crambe tailliezi & 14.7 & 7.51 \\
P3 & Sponge Crambe tailliezi & 7.58 & 2.63 \\
\hline
\end{tabular}

Extracts and P3 compound were tested at various concentrations on human Aurora A and B kinases to calculate the $\mathrm{IC}_{50}$ values. Activities were assessed in duplicate using the ADP-Glo luminescent assay, using $10 \mu \mathrm{M}$ ATP. N/A: nonactive at the maximal concentration tested. 


\subsection{P3 Inhibits the Viability of Human Cancer Cell Lines}

The kinase-based screening showed an inhibition of Aurora A and B kinases by P3. These proteins are important for faithful transition through mitosis. They are overexpressed in a wide variety of human tumors and are thus considered as pertinent targets for developing new cancer therapies. Known inhibitors of Aurora A and B, such as Alisertib (MLN8237) [30,31], display antiproliferative activity in a wide range of human tumor cell lines [32-34]. The effect of P3 on cell viability was thus explored.

P3 was tested on nine human cancer cell lines: Hep G-2 (hepatocellular carcinoma), MCF-7 (breast adenocarcinoma), U-87 (glioblastoma), SH-SY5Y (neuroblastoma), HT-29 (colorectal adenocarcinoma), U-2 OS (osteosarcoma), PANC-1 (pancreatic epithelioid carcinoma), AsPC-1 (pancreatic adenocarcinoma), A3 (acute T cell leukemia). Four noncancerous cell lines were also tested: hTERT RPE-1 (human retinal pigmented epithelial cell line), RC-124 (kidney primary cell line), HEK-293 (embryonic kidney cell line), HT-22 (mouse hippocampal neuronal cell line). As shown in Table 3, a $24 \mathrm{~h}$ exposure with P3 induced a dose-dependent reduction of cell survival in all cell lines tested. When used at $50 \mu \mathrm{g} / \mathrm{mL}$, P3 decreased over $90 \%$ of cell viability after $24 \mathrm{~h}$ of treatment (Figure S3A). The half-maximal effective concentrations $\left(\mathrm{EC}_{50}\right.$ ) of $\mathrm{P} 3$ on cells ranged from 6.6 to $22.4 \mu \mathrm{g} / \mathrm{mL}$ (Table 3 and Figure S3B).

Table 3. Effect of P3 on the viability of various cell lines.

\begin{tabular}{cccc}
\hline Cell type & Cell line & Tissue & EC $_{\mathbf{5 0}}(\boldsymbol{\mu g} / \mathbf{m L}) \pm$ SD \\
\hline Leukemia & A3 & T lymphocyte & $7.0 \pm 0.6$ \\
\hline Solid malignancies & U-2 OS & Bone & $6.6 \pm 0.2^{*}$ \\
& SH-SY5Y & Bone marrow & $8.9 \pm 0.2$ \\
& U-87 & Brain & $10.6 \pm 0.5$ \\
& Hep G-2 & Liver & $11.8 \pm 1.6$ \\
& MCF-7 & Breast & $12.2 \pm 1.6$ \\
& AsPC-1 & Pancreas & $12.4 \pm 0.6$ \\
& HT-29 & Colon & $20.4 \pm 0.7$ \\
& PANC-1 & Pancreas & $22.4 \pm 1.4$ \\
\hline Non-malignant & hTERT RPE-1 & Retina, eye & $7.2 \pm 0.4$ \\
& HEK-293 & Kidney & $11.2 \pm 0.6$ \\
& RC-124 & Kidney & $13.3 \pm 0.8$ \\
& HT-22 & Brain (mouse) & $14.0 \pm 1.2$
\end{tabular}

Cells were incubated with increasing doses of P3 (ranging from 0.01 to $50 \mu \mathrm{g} / \mathrm{mL}$ ). Human cells were used, except HT-22, an immortalized mouse hippocampal cell line. Cell viability was measured by MTS reduction assay as mentioned in the Materials and Methods. $E_{50}$ values are determined from the dose-response curves using GraphPad PRISM software (data are mean, $n=3$; and ${ }^{*} n=6$ for U-2OS).

Further investigations on the mechanism(s) by which P3 affects cell viability were carried out in $\mathrm{U}-2 \mathrm{OS}$ cells, the most sensitive solid tumor-derived cell line of the panel used here. Cell viability was evaluated by detection of MTS reduction. As the reduction of tetrazolium reagents can be occasionally observed under conditions in which cell death does not occur, the lactate dehydrogenase (LDH) release assay was also used as an independent cell death assay. As shown in Figure 5, the treatment of U-2 OS with increasing doses of $\mathrm{P} 3$ product induced a dose-dependent reduction of cell survival that correlated with the similar dose-dependent induction of cell death. 


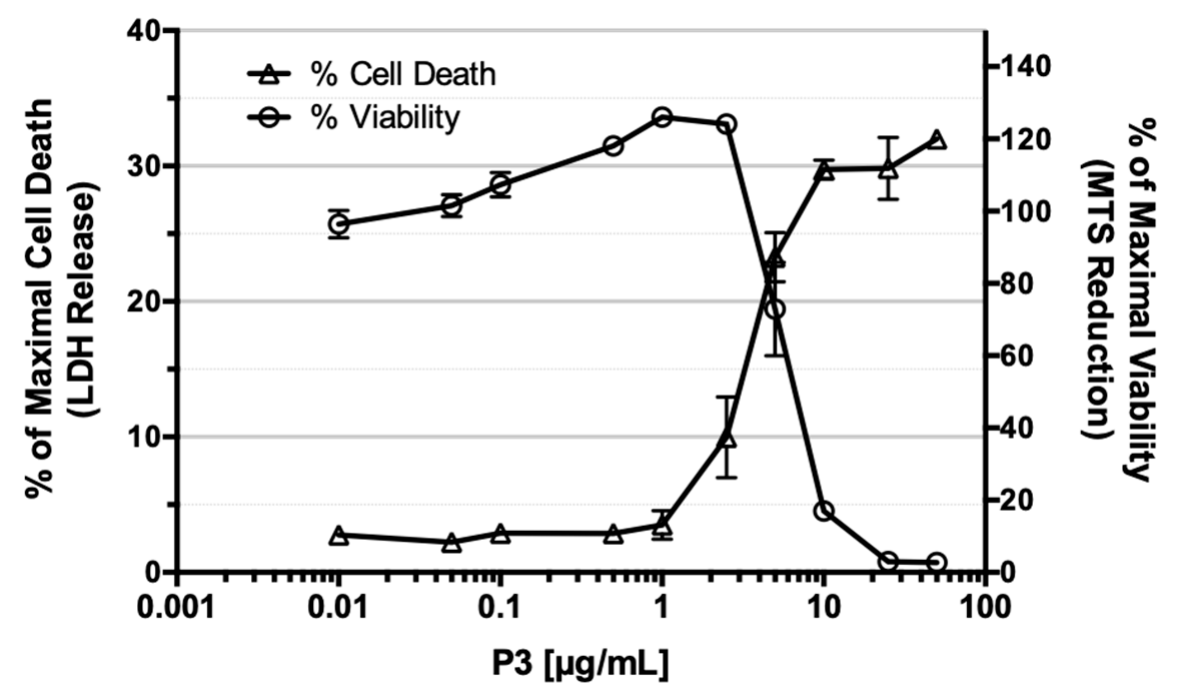

Figure 5. Dose-dependent induction of cell death in U-2 OS cells by P3 product. U-2 OS cells were exposed for $24 \mathrm{~h}$ to increasing concentrations of $\mathrm{P} 3$ (ranging from 0.01 to $50 \mu \mathrm{g} / \mathrm{mL}$ ). Cell viability was assessed by MTS reduction assay and is plotted in \% of maximal viability (detected in DMSO-treated cells, right axis). A similar experiment was performed to evaluate cell death (LDH release assay, left axis). Results are plotted in \% of maximal LDH release (cell lysis). Data are mean \pm SD $(n=3)$.

\subsection{P3 Induces Apoptotic Death in Osteosarcoma U-2 OS Cell Line}

In order to visualize the dynamics of living cell nuclei, we imaged U-2 OS cells expressing Histone H2B fused to the RFP (red fluorescent protein), treated or not with $7.5 \mu \mathrm{g} / \mathrm{mL}$ of P3. The results obtained indicated that, in P3-treated cells, chromatin became hypercondensed (strong fluorescent signal), starting from $5 \mathrm{~h}$ after the beginning of treatment ( $1 \mathrm{~h}$ of movie time) (Figure 6A). By $6 \mathrm{~h}$ of treatment, all nuclei showed condensed chromatin, a typical phenotype of apoptotic cells. Note that the cell with condensed chromatin, appearing in the control culture by $2 \mathrm{~h}$ of movie time, is in mitosis and ultimately divided (see Supplementary Materials Section, Videos S1 and S2). In addition, the mitotic index (MI), the ratio of mitotic cell number over total cell number, was also measured. A significant decrease of the mitotic index was detected in P3-treated cells $(0.7 \%)$, compared with control cells $(4.4 \%)$ (Figure $6 \mathrm{~B})$, suggesting that cell division was severely affected.

The dose- and time-dependent effects of P3 on cell proliferation and on externalization of phosphatidylserine (an early apoptosis feature) were then evaluated in U-2 OS cells, by real-time live-imaging (Figure 6C,D). The evolution of cell confluence (Figure 6C) as well as the number of apoptotic cells, by annexin V staining (Figure 6D), were also measured. The results obtained confirmed that treatments with 2.5 to $12.5 \mu \mathrm{g} / \mathrm{mL}$ of P3 inhibited cellular proliferation and induced apoptosis simultaneously. Higher dose of P3 $(25 \mu \mathrm{g} / \mathrm{mL}$ ) induced massive cell death (Figure 6C,D). To confirm the effect of P3 treatment on tumor cell proliferation, a scratch wound migration assay was used (Figure S4). We observed a delay in wound closure after $48 \mathrm{~h}$ of treatment with P3 at 5 and $12.5 \mu \mathrm{g} / \mathrm{mL}$, which occurred concomitantly to cell death. 


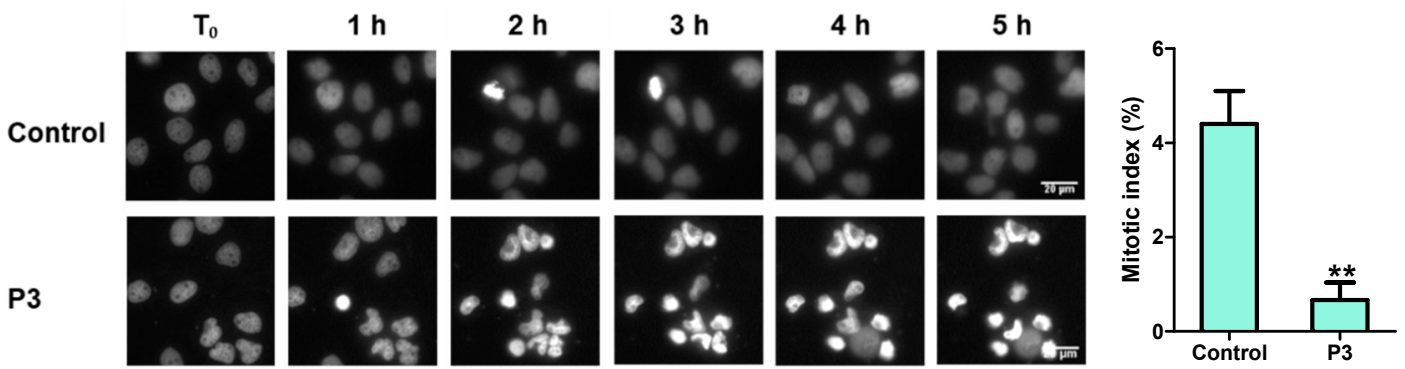

A

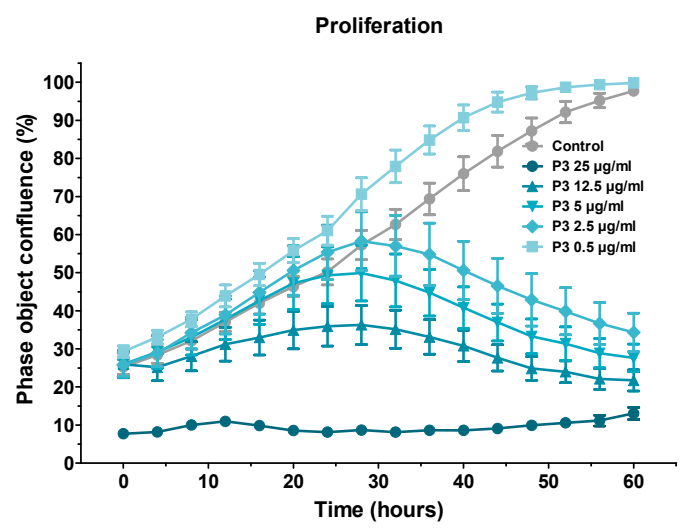

C

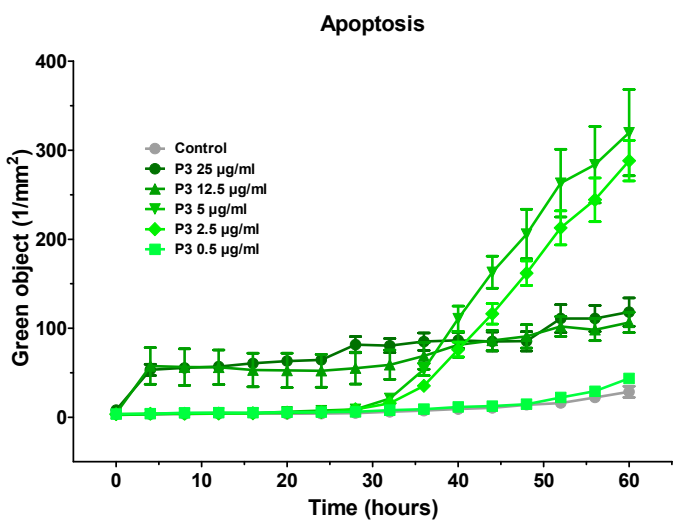

D

Figure 6. $\mathrm{P} 3$ induces apoptosis and affects mitosis in U-2 OS cells. (A) Real-time imaging of chromatin dynamics in P3-treated U-2 OS cells expressing Histone H2B-RFP. Image recording started $4 \mathrm{~h}$ after treatment with $7.5 \mu \mathrm{g} / \mathrm{mL}$ of $\mathrm{P} 3$, by fluorescence microscopy at $20 \times$ magnification. (B) Mitotic indexes of cells were recorded after $24 \mathrm{~h}$ of treatment with $7.5 \mu \mathrm{g} / \mathrm{mL}$ of P3. Five hundred cells/condition were analyzed. Data are mean $\pm \operatorname{SD}(n=3) ;{ }^{* *} P<0.01$, compared with control cells (Student's $t$-test). Doseand time-dependent effects of P3 on cell proliferation (C) and on apoptosis (D) in U-2 OS cells. Cells were stained with annexin V-FITC and treated with P3 $(0.5-25 \mu \mathrm{g} / \mathrm{mL})$ over $60 \mathrm{~h}$. Images were acquired by real-time live-cell imaging. Images were analyzed in order to quantify cell confluence $(\mathbf{C})$ and apoptotic cell number (green fluorescent object) (D). Data are mean $\pm \operatorname{SD}(n=3)$.

\subsection{Characterization of P3-Induced Apoptotic Death in Osteosarcoma U-2 OS Cells}

We next investigated the type of P3-induced cell death in U-2 OS cells. Cells were treated with three concentrations $(5,7.5$, and $12.5 \mu \mathrm{g} / \mathrm{mL})$ of P3 for $24 \mathrm{~h}$ in the presence or in absence of reference inhibitors of two programmed cell death subroutines: (i) Z-VAD-FMK (pan-caspase inhibitor that inhibits caspase-dependent apoptosis) [35] or (ii) necrostatin-1s (nec-1s, specific inhibitor of receptor-interacting kinase-1, RIPK1 kinase, which inhibits necroptosis and RIPK1-dependent apoptosis) [36]. Cell viability was measured using MTS reduction assay. As reported on Figure 7A, P3 strongly reduced cell survival $(40 \%$ at $7.5 \mu \mathrm{g} / \mathrm{mL}$ and $80 \%$ at $20 \mu \mathrm{g} / \mathrm{mL})$. This effect, obtained with $7.5 \mu \mathrm{g} / \mathrm{mL}$ of P3, was significantly reversed by $10 \mu \mathrm{M}$ and $50 \mu \mathrm{M}$ of Z-VAD-FMK, indicating a role of caspases in the mechanism of action of P3 compound (see also the Figure S5, left panel). Oppositely, the effect of P3 on cell survival was not inhibited by $50 \mu \mathrm{M}$ of nec-1s. This data suggests that RIPK1 is not involved in the cellular effects triggered by P3. High doses of a less specific inhibitor of RIPK1, necrostatin-1 (Figure S5, right panel), were also tested. Interestingly, $50 \mu \mathrm{M}$ and $125 \mu \mathrm{M}$ of nec-1 were shown to inhibit significantly the effect of P3 on cell survival, suggesting a possible role of unknown off-targets of nec- 1 in the death process initiated by P3. 

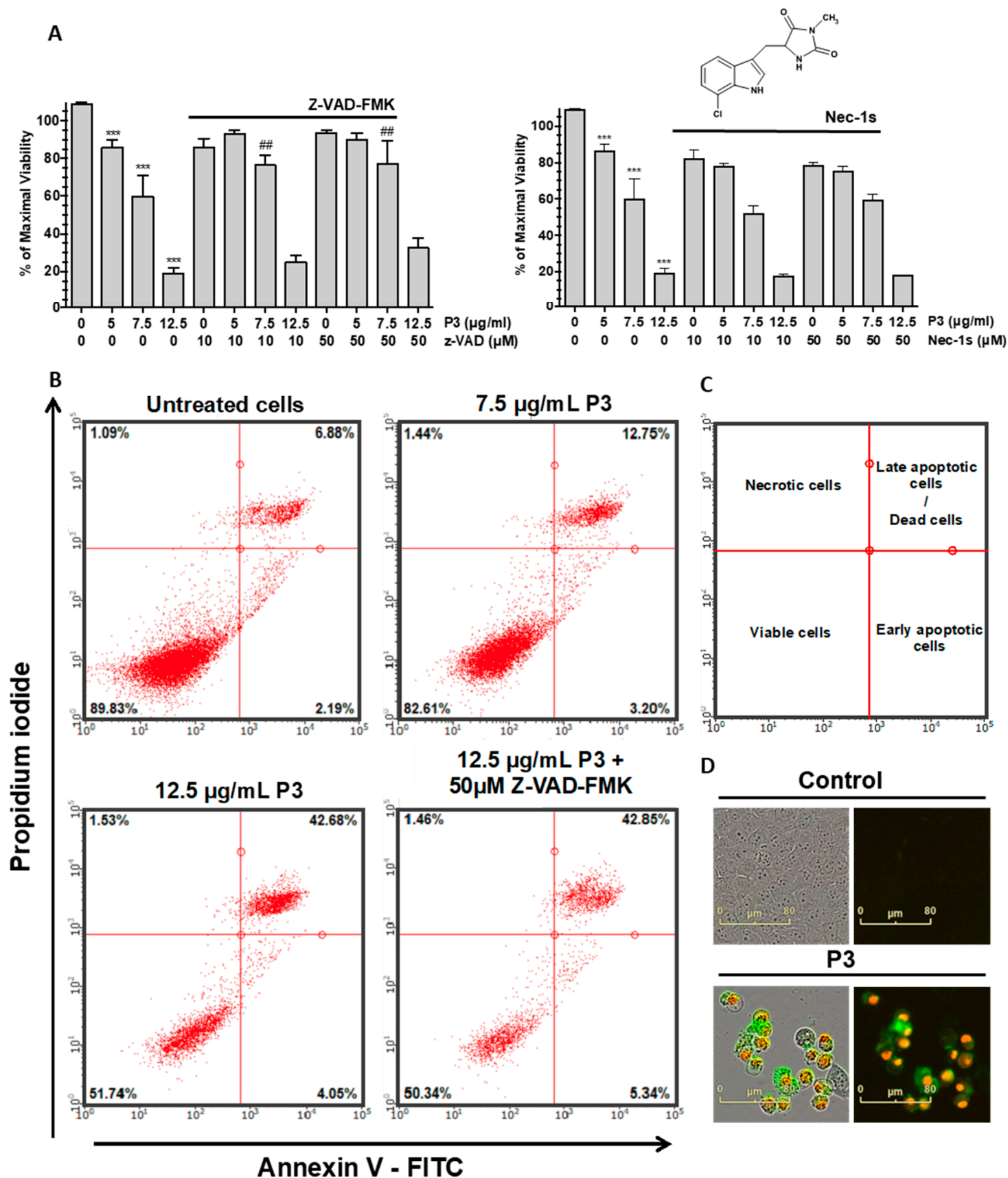

C

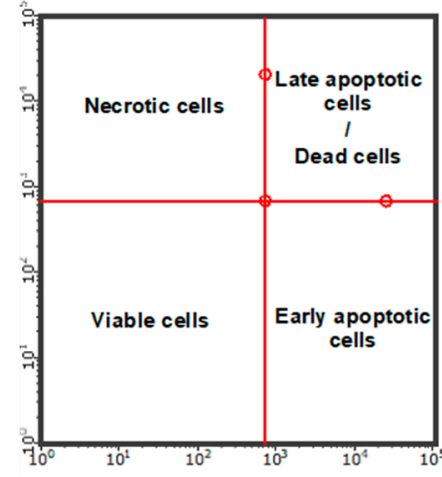

D

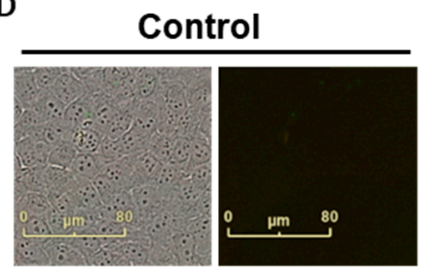

P3

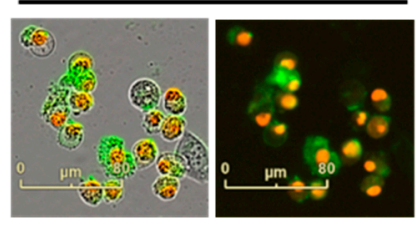

Figure 7. Analysis of apoptosis pathway induced by P3 in U-2 OS cells. (A) P3-induced inhibition of cell survival in U-2 OS cells. Cells were treated with Z-VAD-FMK $(10$ or $50 \mu \mathrm{M})$ or Nec-1 (10 or $50 \mu \mathrm{M})$ and P3 (7.5 or $12.5 \mu \mathrm{g} / \mathrm{mL})$ for $24 \mathrm{~h}$. Cell viability was measured by MTS reduction assay. Data are mean $\pm \mathrm{SD}(n=3) ;{ }^{* * *} P<0.001$ compared with control cells; \#\# $P<0.01$, compared with $7.5 \mu \mathrm{g} / \mathrm{mL}$ P3 without Z-VAD-FMK group (Student's $t$-test). (B) Apoptosis detection by flow cytometry (FACS) analysis after annexin V-FITC/PI staining after a $24 \mathrm{~h}$ treatment of U-2 OS cells by DMSO (untreated control cells), $7.5 \mu \mathrm{g} / \mathrm{mL}$ or $12.5 \mu \mathrm{g} / \mathrm{mL}$ of $\mathrm{P} 3$ compound and $12.5 \mu \mathrm{g} / \mathrm{mL}$ of P3 compound with $50 \mu \mathrm{M}$ of Z-VAD-FMK. (C) Schematic description of cell repartition in each quadrant from the experiment in B. (D) Visualization of the cells treated for $24 \mathrm{~h}$ with P3 by microscopy. Cell were labelled as in B, with annexin V FITC (green) et PI (red). Representative merged phase-contrast/fluorescence and fluorescence images were taken at $20 \times$ magnification.

Consequently, apoptotic cells were quantified by flow cytometry. After $24 \mathrm{~h}$ of treatment with P3, U-2 OS cells were stained with both annexin V conjugated to fluorescein isothiocyanate (FITC annexin 
V) and PI (propidium iodide) to detect necrosis and early or late apoptosis in total cell population (as shown on Figure 7C). We found that P3 induced mostly late apoptosis in treated cells ( $42.6 \%$ of total cell population when treated with $12.5 \mu \mathrm{g} / \mathrm{mL}$ of P3, Figure 7B). The effect of $50 \mu \mathrm{M}$ of Z-VAD-FMK was also tested and showed that this high dose of pan-caspase inhibitor cannot inhibit the late apoptosis triggered by $\mathrm{P} 3$.

The P3-induced apoptosis was also observed by microscopy (Figure 7D). It is accompanied with apoptosis morphological changes (cell roundup and nuclear condensation) and with positive signals for both annexin V and PI staining, the hallmark of the late apoptosis phase.

\subsection{P3 Affects U-2 OS Spheroids Viability and Integrity}

As the effect of P3 on programmed cell-death of two-dimensional (2D) monolayer cells was validated, we next investigated in vitro effect on single spheroids as experimental models of three-dimensional (3D) cell populations. Multicellular spheroid cultures were initially developed in 1970 to recapitulate the functional phenotype of human tumor cells and their responses to radiotherapy [37,38]. Compared to the traditional 2D format, the 3D spheroid system provides a more accurate and reproducible model for drug development: they are able to closely mimic the main features of human solid tumors, including the structural organization, increased cell survival as well as nutrient, metabolite, and oxygen gradients. Numerous studies have shown a good correlation between 3D- culture experiments and clinical trials, especially in human solid tumors [39]. In order to study the effect of $\mathrm{P} 3$ on 3D-cell culture, U-2 OS spheroids were generated and treated them with P3. The viability of spheroids was estimated by MTS reduction assay after a $96 \mathrm{~h}$ treatment. As shown in $6 \mathrm{~A}$, treatments with 12.5 and $25 \mu \mathrm{g} / \mathrm{mL}$ of P3 significantly reduced the viability of spheroids. To complete this analysis, the morphology as well as the size of spheroids were next observed by microscopy. The data obtained indicated that a treatment of U-2 OS spheroids with $12.5 \mu \mathrm{g} / \mathrm{mL}$ of P3 expanded and collapsed the three-dimensional cellular organization of the spheroids (Figure 8B).

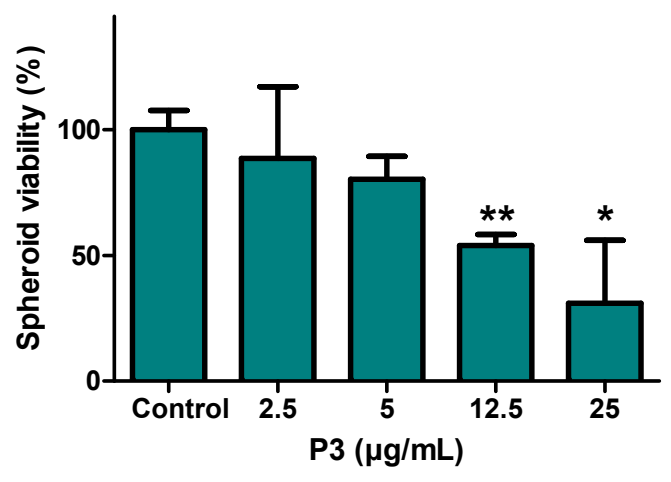

A

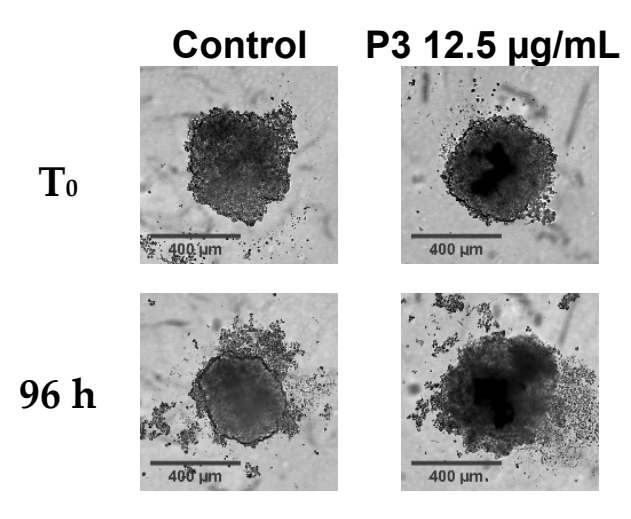

B

Figure 8. Effects of $\mathrm{P} 3$ on the growth and viability of U-2 OS spheroids. (A) Dose-dependent effect of a $96 \mathrm{~h}$ treatment with P3 (from 2.5 to $25 \mu \mathrm{g} / \mathrm{mL}$ ) on the viability of U-2 OS spheroids. Spheroid viability was quantified by MTS reduction assay. Data are mean $\pm \operatorname{SD}(n=3) ;{ }^{*} P<0.05,{ }^{* *} P<0.01$, compared with DMSO-treated control spheroids (Student's t-test). (B) Spheroid morphology was analyzed by microscopy. Bright field images showing the morphology of U-2 OS spheroids were taken at $4 \times$ magnification using IncuCyte ${ }^{\circledR}$ (Sartorius, Ann Arbor, MI, USA.). 


\section{Discussion}

In the present work, we used a protein kinase target-based screening strategy to identify extracts from marine organisms with potential bioactivity. We isolated a high molecular weight metabolite, P3, from the sponge Crambe tailliezi (sampled in the Mediterranean Sea) as a new cytotoxic marine natural product that inhibits the Aurora protein kinases. Note here that one of the 50 FDA-approved protein kinase inhibitors is Midostaurin (as Rydapt ${ }^{\circledR}$, Novartis Pharmaceuticals, Inc.). This direct derivative of staurosporine is a multitarget kinase inhibitor for the treatment of adult patients with newly diagnosed acute myeloid leukemia (AML) who harbor mutations in FMS-like tyrosine kinase 3 (FLT3) [40]. Both are indolocarbazole alkaloids that can be found in numerous marine species from invertebrates (e.g., from the ascidian Eudistoma toealensis) to marine sponge-associated actinomycetes [15,41].

Within the Crambeidea family, Crambe tailliezi [23], is an encrusting marine sponge also scarcely distributed in the Mediterranean and the Macaronesian Seas, which remains poorly investigated for either its chemical composition or the biological properties of its metabolites, contrary to Crambe crambe [24] that has been widely explored chemically since the 90s [25-27]. Among the compounds already described in C. crambe, the guanidine alkaloids, crambescins, and crambescidins showed a wide range of bioactivities such as antibacterial, antiviral, and antifungal properties and cytotoxic activities against several cancer cell lines [28,42-44]. The present study is thus focused on an untapped marine resource.

The primary screening performed on a selected panel of protein kinases showed that C. tailliezi P3 is a dual inhibitor of Aurora A and B kinases. Aurora kinases are known to play pleiotropic roles during mitosis. They are notably important for the capture, alignment, and segregation of chromosomes and thus were subjects of intensive screening campaign to characterize new potent inhibitors: $50+$ clinical trials were performed in solid and hematological tumors [45]. Following the screening of kinases, we showed that P3 decreased the viability of two- and three-dimensional cell cultures and induced apoptosis of U-2 OS cells.

Numerous cell death subroutines are now described and classified as reported by Galluzzi et al. [4]. Here, we showed that P3 induces an apoptotic-like programmed cell death. Indeed, these results suggested that caspases have no crucial role in the process triggered by P3. As shown by FACS analysis, even cotreated with $50 \mu \mathrm{M}$ of Z-VAD-FMK, the cells died by late apoptosis (PI+/Annexin V-FITC+). It has been proposed that no single experimental system exists in which Z-VAD-FMK can save cells from dying [46]. Consequently, additional studies will be crucial to prove that active caspases are not a prerequisite for execution of cell death induced by P3. Interestingly, the effect of P3 on cell survival was not inhibited by $50 \mu \mathrm{M}$ of nec-1s, whereas the same dose of a less specific inhibitor of RIPK1, nec-1, can inhibit this phenotype. This indicates that P3 induces necrostatin-1-inhibitable cell death independent of RIPK1 kinase as it was previously observed for nitric oxide-induced cell-death of pancreatic $\beta$-cells [47]. It would be now very important to characterize the targets of necrostatin- 1 that are responsible for this inhibition. This chemobiological approach should provide crucial insights to pinpoint the molecular pathway involved in P3-induced cell death.

Structural determination of P3, based on chemical degradation, NMR, and MS analyses, was unsuccessful due to the low quantities of P3 and its associated fragments recovered after isolation. Similarly, another preliminary study reported also that isolation and structure elucidation of the major compound produced by C. tailliezi is extremely complicated [48]. New strategies have now to be explored such as the cocrystallization of purified P3 metabolite with Aurora A or B kinase following X-ray structure determination. 


\section{Materials and Methods}

\subsection{Sample Material}

Cliona viridis (Schmidt, 1862), Axinella polypoides (Schmidt, 1862), Axinella sp., Cacospongia sp., Crambe crambe (Schmidt, 1862), Crambe tailliezi (Vacelet \& Boury-Esnault, 1982), Acanthella acuta, Agelas oroides (Schmidt, 1864), Hemimycale columella (Bowerbank, 1874), Ircinia oros (Schmidt, 1864), Ircinia variabilis (Schmidt, 1862), Phorbas topsenti (Vacelet \& Pérez, 2008), Pleraplysilla spinifera (Schulze, 1879), Pseudaxinyssa sp., Reniera fulva (Topsent, 1893), Reniera mucosa (Griessinger, 1971), Reniera sarai (Pulitzer-Finali, 1969), Sarcotragus foetidus (Schmidt, 1862), Sarcotragus spinosulus (Schmidt, 1862), were sampled in Villefranche-sur-Mer (France) in 2011. Aplidium sp., Cystodytes sp., Halocynthia papillosa (Linnaeus, 1767), Polysyncraton sp., Haliclona mediterranea (Griessinger, 1971), Hexadella sp., Oscarella sp. Axinyssa sp. were sampled in Pota del Llop (Spain) in 2012. All the marine species were identified by Philippe Amade and Mathieu Foulquié.

\subsection{Preparation of Natural Extracts and of P3 Pure Compound}

All the solvents (analytical grade), formic acid and 2,5-dihydroxybenzoic acid (DHB) were purchased from Sigma Aldrich (France). NMR $\left({ }^{1} \mathrm{H}\right.$ and ${ }^{13} \mathrm{C}$ ) and MALDI-TOF analyses were performed as described in [49].

HPLC-PDA-ELSD analyses were performed with a Waters Alliance 2695 HPLC system (Waters Corporation, Milford, MA) coupled with a Waters 996 photodiode array detector and a Sedex 55 evaporative light-scattering detector (SEDERE, France), using a bifunctional Macherey-Nagel NUCLEODUR ${ }^{\circledR}$ Sphinx RP column $(250 \times 4.6 \mathrm{~mm}, 5 \mu \mathrm{m})$ consisting of a balanced ratio of propylphenyl and $\mathrm{C} 18$ ligands. The mobile phase was composed of $\mathrm{H}_{2} \mathrm{O}$ (plus $\left.0.1 \% \mathrm{HCO}_{2} \mathrm{H}\right)$ and acetonitrile $\left(\mathrm{CH}_{3} \mathrm{CN}\right.$ plus $0.1 \% \mathrm{HCO}_{2} \mathrm{H}$ ) and the following gradient was used: $\mathrm{H}_{2} \mathrm{O}: \mathrm{CH}_{3} \mathrm{CN} 90: 10$ for $5 \mathrm{~min}, \mathrm{H}_{2} \mathrm{O}: \mathrm{CH}_{3} \mathrm{CN}$ 90:10 to 0:100 for $30 \mathrm{~min}$, 0:100 for $5 \mathrm{~min}, 0: 100$ to $90: 10$ for $15 \mathrm{~min}$ (flow: $1.0 \mathrm{~mL} . \mathrm{min}^{-1}$, injection volume: $20 \mu \mathrm{L}$ ). Chromatograms were extracted at the following detection wavelengths for visual inspection: 214, 254, and $280 \mathrm{~nm}$.

Each freeze-dried species was grounded to give a dry powder $(1 \mathrm{~g})$, extracted three times during $10 \mathrm{~min}$ with $10 \mathrm{~mL}$ of a mixture of $\mathrm{MeOH} / \mathrm{CH}_{2} \mathrm{Cl}_{2}(1: 1, \mathrm{v} / \mathrm{v})$ in an ultrasonic bath. The filtrates of each extraction were combined, mixed with $0.5 \mathrm{~g}$ of RP C18 silica gel and evaporated to dryness. The latter were then loaded onto $\mathrm{C} 18$ solid phase extraction (SPE) cartridges beforehand conditioned ( $2 \mathrm{~g}$, Phenomenex Strata). The SPE columns were first washed with $10 \mathrm{~mL}$ of $\mathrm{H}_{2} \mathrm{O}$ for desalting and then eluted with $10 \mathrm{~mL}$ of $\mathrm{MeOH} / \mathrm{CH}_{2} \mathrm{Cl}_{2}(1: 1, \mathrm{v} / \mathrm{v})$ in a $20 \mathrm{~mL}$ volumetric flask. The resulting organic phase, obtained after concentration under reduced pressure, were used for HPLC-PDA-ELSD analyses and biological screenings.

Desalted crude organic extract of Crambe tailliezi $(128 \mathrm{mg})$ was fractionated by size exclusion chromatography (Sephadex LH-20) in $\mathrm{MeOH}$ to afford six fractions (Fr. 1-6). Fraction 3 yielded pure compound P3 (46.8 mg).

Finally, each crude organic extract was analyzed by HPLC/ESI-MS/MS in both positive and negative ion modes (see [50] for details on the methods used).

\subsection{Protein Kinase Assays}

In order to measure kinase activity, the ADP-Glo ${ }^{\text {TM }}$ assay kit (Promega, Madison, WI, USA) was used according to manufacturer's recommendations (see [51] for details on this method). The experimental conditions used to perform the various kinase assays are reported in Supplementary Table S1.

\subsection{Cell Lines and Cell Culture}

Dulbecco's Modified Eagle's Medium (DMEM), RPMI 1640 Medium, DMEM/F-12 Medium, Fetal Bovine Serum (FBS), Penicillin-Streptomycin (5000 U/mL), Trypsin-EDTA (0.25\%), Phosphate-Buffered Saline (PBS) were obtained from Thermo Fisher Scientific (USA). The human cell lines A3, U-2 OS, 
SH-SY5Y, U-87, Hep G-2, MCF-7, AsPC-1, HT-29, PANC-1, hTERT RPE-1, HEK-293, RC-124, and the mouse cell line HT-22 used in this study were obtained from ATCC (American Type Culture Collection, Rockville, MD, USA) and cultured in medium supplemented with 10\% FBS, $50 \mathrm{U} / \mathrm{mL}$ penicillin and $50 \mu \mathrm{g} / \mathrm{mL}$ streptomycin. The cells were incubated under a $5 \% \mathrm{CO}_{2}$ atmosphere at $37^{\circ} \mathrm{C}$ and passed twice a week for a use within two months.

\subsection{Cell Viability and LDH-Release Assays}

Evaluation of cell viability: From $5.0 \times 10^{4}$ to $2.0 \times 10^{5} / \mathrm{mL}$ cells were seeded in 96-well plates (\#CC7682-7596, CytoOne®, USA) following $24 \mathrm{~h}$ of incubation. Cells were exposed to compounds for $24 \mathrm{~h}, 48 \mathrm{~h}$, or $72 \mathrm{~h}$. Cell viability was determined by MTS reduction assay (CellTiter 96®AQueous One Solution Cell Proliferation Assay from Promega, Madison, WI, USA), according to the manufacturer's instructions. This method is based on the reduction of MTS tetrazolium compound by viable cells to generate a colored formazan product. After treatment with the tested compounds, cells were incubated with MTS (3-(4,5-dimethylthiazol-2-yl)-5-(3-carboxymethoxyphenyl)-2-(4-sulfophenyl)-2H-tetrazolium, Inner salt) for $3 \mathrm{~h}$ at $37^{\circ} \mathrm{C}$. The absorbance was measured with microplate reader BioTek EL800 (BioTek Instruments, Inc., USA) at 490 and $630 \mathrm{~nm}$. The percentage of viability was calculated by comparing values obtained from treatments with tested compounds to those of DMSO (used as control). Staurosporine, Z-VAD-FMK and necrostatin-1 were purchased from Enzo Life Science (Villeurbanne, France).

Evaluation of cell death: $5.0 \times 10^{3} \mathrm{U}-2$ OS-cells were seeded per well in 96-well plates following $24 \mathrm{~h}$ of incubation. Cells were exposed to P3 natural product for $24 \mathrm{~h}$. Cell death was evaluated by measurement of activity of lactate dehydrogenase (LDH). LDH is a stable enzyme normally found in the cytosol of all cells but rapidly releases into the supernatant upon damage of plasma membrane. The $\%$ of maximal cell death was determined by using the CyQUANT ${ }^{\mathrm{TM}}$ LDH Cytotoxicity Assay Kit (Invitrogen, Carlsbad, CA, USA), according to the manufacturer's instructions.

\subsection{Time-Lapse Assay}

The cell line U-2 OS H2B-RFP, which expresses Histone 2B fused to red fluorescent protein, was used to observe chromosome dynamics in live cells. Cells (25 000 cells/well) were seeded in four-well plates adapted to video-microscopy (Lab-Tek II Chamber coverglass, Thermo Fisher Scientific, USA) for $24 \mathrm{~h}$. Cells were exposed to P3 or DMSO for $24 \mathrm{~h}$. During the treatment time, cells were visualized under an inverted fluorescence microscopy (Zeiss, Germany) and images were recorded every 20 min by an EMCCD camera (Zeiss, Germany). Images were analyzed by MetaMorph ${ }^{\circledR}$ Software (MetaMorph Inc., USA).

\subsection{Live-Cell Imaging of Apoptosis in U-2 OS}

U-2 OS cells (5 000 cells/well) were seeded in 96-well plates (\#CC7682-7596, CytoOne®, USA) $24 \mathrm{~h}$ prior to treatment. Cells were then exposed to compounds for as long as $60 \mathrm{~h}$. During the treatment, cell morphology was observed and images recorded using an automatic microscope IncuCyte ${ }^{\circledR}$ S3 Live-Cell Analysis System (Sartorius, Ann Arbor, MI, USA). Moreover, cells were stained with FITC Annexin V Apoptosis Detection Kit I (\#556547, BD Biosciences, USA) to detect cell apoptosis. Cell confluence (phase object) and apoptotic cell number (green fluorescent object) were analyzed with IncuCyte ${ }^{\circledR}$ S3 Software.

\subsection{Detection of Apoptosis by Flow Cytometry}

In early apoptotic cells, phosphatidylserine (PS) is translocated from the inner to the outer leaflet of the plasma membrane, thus exposing PS to the external cellular environment. Annexin V labelled with fluorescein has a high affinity for PS exposed on the outer leaflet and is used to identify apoptotic cells $[52,53]$. PI intercalating DNA enters the cells in the case of late apoptosis or necrosis where the cellular membrane becomes permeable [54]. Living cells give negative signals with both annexin $\mathrm{V}$ 
and PI. In this assay, U-2 OS cells (50 000 cells/well) were seeded in 12-well plates (\#CC7682-7512, CytoOne $囚$, USA) for $24 \mathrm{~h}$. Cells were exposed to compounds for $24 \mathrm{~h}$. Cells were harvested, washed twice with cold PBS, and then resuspended in $1 \times$ Binding Buffer. Finally, cells were stained with FITC Annexin V Apoptosis Detection Kit I (\#556547, BD Biosciences, USA) for $15 \mathrm{~min}$ at RT $\left(25^{\circ} \mathrm{C}\right.$ ) in the dark. The stained cells were analyzed by flow cytometer BD FACSCanto II (BD Biosciences, USA). Data were analyzed with BD FACSDiva Software 8.0 (BD Biosciences, USA). Each experiment was performed in duplicate.

\subsection{Scratch Wound Assay to Evaluate the Cellular Migration and Proliferation}

U-2 OS cells (20 000 cells/well) were grown in DMEM with 10\% FBS in 96-well ImageLock plates (\#4379, Essen BioScience, USA) for $6 \mathrm{~h}$ to reach approximately 100\% of confluence. The ImageLock ${ }^{\circledR}$ plate technology is enabled by fiducial markers on the bottom of the plate which provide points from which image locations can be accurately referenced. After creating wounds using the IncuCyte ${ }^{\circledR}$ WoundMaker (96-pin wound making tool), cells were washed twice with DMEM then exposed to compounds for $72 \mathrm{~h}$. During the treatment, cell morphology was observed by using IncuCyte ${ }^{\circledR} \mathrm{S} 3$ Live-Cell Analysis System (Sartorius, Ann Arbor, MI, USA). Data were analyzed with IncuCyte ${ }^{\circledR}$ S3 Software. Data were analyzed with IncuCyte ${ }^{\circledR}$ S3 Software.

\subsection{Spheroid Assay}

U-2 OS cells (5000 cells/well) were seeded in Corning®96-well Round Bottom Ultra Low Adhesion-ULA plates (\#7007, Corning Incorporated, USA). After being centrifuged at 1000 RPM for $10 \mathrm{~min}$, plates were incubated under a $5 \%$ of $\mathrm{CO}_{2}$ at $37{ }^{\circ} \mathrm{C}$ for $72 \mathrm{~h}$ to produce spheroids $(400 \mu \mathrm{m}$ diameter). Spheroids were then treated with compounds for $96 \mathrm{~h}$. During the treatment, cell morphology was observed using IncuCyte ${ }^{\circledR}$ S3 Live-Cell Analysis System (Sartorius, Ann Arbor, MI, USA). Data were analyzed with IncuCyte ${ }^{\circledR}$ S3 Software: the size of the spheroids was measured using an automated algorithm that masked the largest brightfield object in the field of view. After $96 \mathrm{~h}$ of treatment, viability of spheroids was also quantified by MTS reduction assay (CellTiter 96®AQueous One Solution Cell Proliferation Assay from Promega, Madison, WI, USA).

\subsection{Statistical Analyses}

Data were acquired from a minimum of three independent experiments. They are expressed as means \pm SD. Statistical analyses were performed with Student's $t$-test or one-way ANOVA. All statistical analyses were performed with GraphPad Prism6 software (GraphPad Software, San Diego, CA, USA).

\section{Conclusions}

In summary, the results reported here show that the high molecular weight metabolite P3 extracted from the Mediterranean sponge C. tailliezi is able to inhibit Aurora A and B protein kinases and to induce apoptotic regulated cell death in U-2 OS human osteosarcoma cells. Taken together, this study should motivate follow up studies on the metabolites from C. tailliezi as a new putative source of anticancer compounds. The purpose of this work was also to underline the use of kinase-based screening as a potent approach to identify new bioactive products from untapped marine resources. Protein kinases constitute one of the largest protein families, accounting for approximately $2 \%$ of the genes in any given eukaryotic genome, and they are critically involved in the regulation of all cellular processes and signaling pathways [55]. The workflow described in this study can be applied to the vast majority of marine extracts and to a wide spectrum of therapeutic applications. 
Supplementary Materials: The following are available online at http://www.mdpi.com/1660-3397/17/10/569/ s1, Video S1: Time-lapse imaging in living human osteosarcoma cells treated with control (DMSO), Video S2: Time-lapse imaging in living human osteosarcoma cells treated with P3. Figure S1: HPLC-PDA-ELSD chromatogram of P3. Figure S2: Dose-dependent effect of extracts E12, E13 and the compound P3 on Aurora A/B kinases activity. Figure S3: Effect of P3 on cell viability of human cancerous and non-cancerous cells. Figure S4: P3 affects proliferation of U-2 OS cells. Figure S5: Effect of co-treatment with P3 and high concentrations of Z-VAD-FMK (A) or necrostatin-1 (B) on the cell viability of U-2 OS cells. Table S1: Experimental conditions used for protein kinase assays.

Author Contributions: Conceptualization, T.-N.-D.N., S.R., M.M. and S.B.; Formal analysis, T.-N.-D.N., O.F., M.M.; Funding acquisition, T.-N.-D.N., S.R., M.M. and S.B.; Investigation, T.-N.-D.N., O.F., E.S., B.B., C.D., A.G., C.M., S.R. and M.M.; Project Administration, S.R., M.M. and S.B.; Resources, E.S., A.G. and M.M.; Supervision, S.R., M.M. and S.B.; Validation, T.-N.-D.N., S.R., M.M. and S.B.; Visualization, T.-N.-D.N., O.F., S.R., M.M. and S.B.; Writing-Original Draft Preparation, T.-N.-D.N.; Writing-Review and Editing, T.-N.-D.N., P.C., S.R., M.M. and S.B.

Funding: This research was funded by the Government of Vietnam/the French Embassy in Vietnam (Campus France)/and the Medicine and Pharmacy University at Hochiminh city (Vietnam) (Thi-Ngoc-Dung Nguyen is recipient of a "Project 911" PhD fellowship), La Ligue Contre le Cancer comity 29, 35, 85, 22 and Région Bretagne ARED (PhD Thesis grant for O. Feizbakhsh); the Cancéropôle PACA; European Union's Horizon 2020 research and innovation program (EMBRIC project, EU grant No 654008); ANR/Investissements d'Avenir program (OCEANOMICs project, grant \#ANR-11-BTBR-0008).

Acknowledgments: Thi-Ngoc-Dung Nguyen is recipient of a "Project 911" PhD fellowship from the Government of Vietnam. We would like to thank the Government of Vietnam, the French Embassy in Vietnam (Campus France) and the Medicine and Pharmacy University at Ho Chi Minh City (Vietnam) for their continuous support of our research. We also would like to thank Dr. Philippe Amade for sampling the biological material, Marc Gaysinski, Lionel Massi (PFTC, ICN, UMR 7272 CNRS), Morgane Ratin and Dominique Marie (Sorbonne Université, CNRS, UMR 7144, Station Biologique de Roscoff), for technical support in RMN, GC-MS and flow cytometry, respectively. The authors thank the Cancéropôle Grand Ouest (axis: natural sea products in cancer treatment), IBiSA (French Infrastructures en sciences du vivant: biologie, santé et agronomie) and Biogenouest (Western France life science and environment core facility network) for supporting the KISSf screening facility, FR2424, Roscoff. O. Feizbakhsh was a recipient of the Région Bretagne ARED fellowship program and is supported by La Ligue Contre le Cancer (CSIRGO). S. Ruchaud is supported by research funding from La Ligue Contre le Cancer (CSIRGO). M. Mehiri is supported by research funding from the Cancéropôle PACA, INCa, the Région PACA SUD and the EMBRIC project (EU grant No 654008). S. Bach is supported by ANR/Investissements d'Avenir program via the OCEANOMICs project (grant \#ANR-11-BTBR-0008) and INCa ("NECROTRAIL" Program). The authors wish to thank Dr. Claude Prigent (IGDR, CNRS/University of Rennes 1) for the generous gift of recombinant Aurora A kinase.

Conflicts of Interest: The authors declare no conflict of interest.

\section{References}

1. Baehrecke, E.H. How death shapes life during development. Nat. Rev. Mol. Cell Biol. 2002, 3, $779-787$. [CrossRef] [PubMed]

2. Lockshin, R.A.; Williams, C.M. Programmed cell death-II. Endocrine potentiation of the breakdown of the intersegmental muscles of silkmoths. J. Insect Physiol. 1964, 10, 643-649. [CrossRef]

3. Lockshin, R.A. Programmed cell death. Activation of lysis by a mechanism involving the synthesis of protein. J. Insect Physiol. 1969, 15, 1505-1516. [CrossRef]

4. Galluzzi, L.; Vitale, I.; Aaronson, S.A.; Abrams, J.M.; Adam, D.; Agostinis, P.; Alnemri, E.S.; Altucci, L.; Amelio, I.; Andrews, D.W.; et al. Molecular mechanisms of cell death: Recommendations of the Nomenclature Committee on Cell Death 2018. Cell Death Differ. 2018, 25, 486. [CrossRef] [PubMed]

5. Fuchs, Y.; Steller, H. Programmed cell death in animal development and disease. Cell 2011, 147, 742-758. [CrossRef] [PubMed]

6. Kerr, J.F.R.; Wyllie, A.H.; Currie, A.R. Apoptosis: A basic biological phenomenon with wide-ranging implications in tissue kinetics. Br. J. Cancer 1972, 26, 239-257. [CrossRef] [PubMed]

7. Nicholson, D.W. Caspase structure, proteolytic substrates, and function during apoptotic cell death. Cell Death Differ. 1999, 6, 1028-1042. [CrossRef]

8. Su, Z.; Yang, Z.; Xie, L.; DeWitt, J.P.; Chen, Y. Cancer therapy in the necroptosis era. Cell Death Differ. 2016, 23, 748-756. [CrossRef]

9. Dixon, S.J.; Lemberg, K.M.; Lamprecht, M.R.; Skouta, R.; Zaitsev, E.M.; Gleason, C.E.; Patel, D.N.; Bauer, A.J.; Cantley, A.M.; Yang, W.S.; et al. Ferroptosis: An iron-dependent form of nonapoptotic cell death. Cell 2012, 149, 1060-1072. [CrossRef] 
10. Conrad, M.; Angeli, J.P.F.; Vandenabeele, P.; Stockwell, B.R. Regulated necrosis: Disease relevance and therapeutic opportunities. Nat. Rev. Drug Discov. 2016, 15, 348-366. [CrossRef]

11. Bergmann, W.; Burke, D.C. Contributions to the study of marine products. XXXIX. The nucleosides of sponges. III.1 spongothymidine and spongouridine2. J. Org. Chem. 1955, 20, 1501-1507. [CrossRef]

12. Hussain, S.; Fareed, S.; Ansari, S.; Sajid Khan, M. Marine natural products: A lead for Anti-cancer. Indian J. Geo-Mar. Sciences 2012, 41, 27-39.

13. Kijjoa, A.; Sawangwong, P. Drugs and Cosmetics from the Sea. Mar. Drugs 2004, 2, 73-82. [CrossRef]

14. Guzmán, E.A. Regulated Cell Death Signaling Pathways and Marine Natural Products That Target Them. Mar. Drugs 2019, 17, 76. [CrossRef] [PubMed]

15. Bharate, S.B.; Sawant, S.D.; Singh, P.P.; Vishwakarma, R.A. Kinase inhibitors of marine origin. Chem. Rev. 2013, 113, 6761-6815. [CrossRef]

16. Skropeta, D.; Pastro, N.; Zivanovic, A. Kinase inhibitors from marine sponges. Mar. Drugs 2011, 9, $2131-2154$. [CrossRef] [PubMed]

17. Li, T.; Wang, N.; Zhang, T.; Zhang, B.; Sajeevan, T.P.; Joseph, V.; Armstrong, L.; He, S.; Yan, X.; Naman, C.B. A Systematic Review of Recently Reported Marine Derived Natural Product Kinase Inhibitors. Mar. Drugs 2019, 17, 493. [CrossRef]

18. Roskoski, R. Properties of FDA-approved small molecule protein kinase inhibitors. Pharmacol. Res. 2019, 144, 19-50. [CrossRef]

19. Carles, F.; Bourg, S.; Meyer, C.; Bonnet, P. PKIDB: A curated, annotated and updated database of protein kinase inhibitors in clinical trials. Molecules 2018, 23, 908. [CrossRef]

20. Kim, E.S. Midostaurin: First global approval. Drugs 2017, 77, 1251-1259. [CrossRef]

21. Manning, G.; Whyte, D.B.; Martinez, R.; Hunter, T.; Sudarsanam, S. The Protein Kinase Complement of the Human Genome. Science 2002, 298, 1912-1934. [CrossRef] [PubMed]

22. Henry, J.; Wlodkowic, D. Towards High-Throughput Chemobehavioural Phenomics in Neuropsychiatric Drug Discovery. Mar. Drugs 2019, 17, 340. [CrossRef] [PubMed]

23. Crambe Tailliezi Vacelet \& Boury-Esnault. 1982. Available online: https://inpn.mnhn.fr/espece/cd_nom/71341 (accessed on 14 January 2019).

24. Crambe Crambe (Schmidt, 1862). Available online: https://inpn.mnhn.fr/espece/cd_nom/71340 (accessed on 14 January 2019).

25. Berlinck, R.G.S.; Braekman, J.C.; Daloze, D.; Bruno, I.; Riccio, R.; Rogeau, D.; Amade, P. Crambines C1 and C2: Two Further Ichthyotoxic Guanidine Alkaloids from the Sponge Crambe crambe. J. Nat. Prod. 1992, 55, 528-532. [CrossRef] [PubMed]

26. Berlinck, R.G.S.; Braekman, J.C.; Daloze, D.; Bruno, I.; Riccio, R.; Ferri, S.; Spampinato, S.; Speroni, E. Polycyclic Guanidine Alkaloids from the Marine Sponge Crambe crambe and $\mathrm{Ca}^{++}$Channel Blocker Activity of Crambescidin 816. J. Nat. Prod. 1993, 56, 1007-1015. [CrossRef]

27. Croué, J.; West, N.J.; Escande, M.-L.; Intertaglia, L.; Lebaron, P.; Suzuki, M.T. A single betaproteobacterium dominates the microbial community of the crambescidine-containing sponge Crambe crambe. Sci. Rep. 2013, 3, 2583. [CrossRef]

28. Sfecci, E.; Lacour, T.; Amade, P.; Mehiri, M. Polycyclic Guanidine Alkaloids from Poecilosclerida Marine Sponges. Mar. Drugs 2016, 14, 77. [CrossRef]

29. Butters, M.; Davies, C.D.; Elliott, M.C.; Hill-Cousins, J.; Kariuki, B.M.; Ooi, L.; Wood, J.L.; Wordingham, S.V. Synthesis and stereochemical determination of batzelladine C methyl ester. Org. Biomol. Chem. 2009, 7, 5001. [CrossRef]

30. Görgün, G.; Calabrese, E.; Hideshima, T.; Ecsedy, J.; Perrone, G.; Mani, M.; Ikeda, H.; Bianchi, G.; Hu, Y.; Cirstea, D.; et al. A novel Aurora-A kinase inhibitor MLN8237 induces cytotoxicity and cell-cycle arrest in multiple myeloma. Blood 2010, 115, 5202-5213. [CrossRef]

31. Zhou, N.; Singh, K.; Mir, M.C.; Parker, Y.; Lindner, D.; Dreicer, R.; Ecsedy, J.A.; Zhang, Z.; Teh, B.T.; Almasan, A.; et al. The investigational Aurora kinase A inhibitor MLN8237 induces defects in cell viability and cell-cycle progression in malignant bladder cancer cells in vitro and in vivo. Clin. Cancer Res. 2013, 19, 1717-1728. [CrossRef]

32. Agnese, V.; Bazan, V.; Fiorentino, F.P.; Fanale, D.; Badalamenti, G.; Colucci, G.; Adamo, V.; Santini, D.; Russo, A. The role of Aurora-A inhibitors in cancer therapy. Ann. Oncol. 2007, 18, 47-52. [CrossRef] 
33. Yeung, S.-C.J.; Gully, C.; Lee, M.-H. Aurora-B kinase inhibitors for cancer chemotherapy. Mini Rev. Med. Chem. 2008, 8, 1514-1525. [CrossRef] [PubMed]

34. Bavetsias, V.; Linardopoulos, S. Aurora kinase inhibitors: current status and outlook. Front. Oncol. 2015, 5, 278. [CrossRef] [PubMed]

35. Zhu, H.; Fearnhead, H.O.; Cohen, G.M. An ICE-like protease is a common mediator of apoptosis induced by diverse stimuli in human monocytic THP.1 cells. FEBS Lett. 1995, 374, 303-308. [CrossRef]

36. Xie, T.; Peng, W.; Liu, Y.; Yan, C.; Maki, J.; Degterev, A.; Yuan, J.; Shi, Y. Structural Basis of RIP1 Inhibition by Necrostatins. Structure 2013, 21, 493-499. [CrossRef]

37. Sutherland, R.M.; Inch, W.R.; McCredie, J.A.; Kruuv, J. A multi-component radiation survival curve using an in vitro tumour model. Int. J. Radiat. Biol. Relat. Stud. Phys. Chem. Med. 1970, 18, 491-495. [CrossRef] [PubMed]

38. Sutherland, R.M.; McCredie, J.A.; Inch, W.R. Growth of multicell spheroids in tissue culture as a model of nodular carcinomas. J. Natl. Cancer Inst. 1971, 46, 113-120. [PubMed]

39. Nunes, A.S.; Barros, A.S.; Costa, E.C.; Moreira, A.F.; Correia, I.J. 3D tumor spheroids as in vitro models to mimic in vivo human solid tumors resistance to therapeutic drugs. Biotechnol. Bioeng. 2019, 116, $206-226$. [CrossRef]

40. Schlenk, R.F.; Kayser, S. Midostaurin: A multiple tyrosine kinases inhibitor in acute myeloid leukemia and systemic mastocytosis. In Small Molecules in Hematology; Martens, U.M., Ed.; Recent Results in Cancer Research; Springer International Publishing: Cham, Switzerland, 2018; pp. 199-214. ISBN 978-3-319-91439-8.

41. Schupp, P.; Eder, C.; Proksch, P.; Wray, V.; Schneider, B.; Herderich, M.; Paul, V. Staurosporine Derivatives from the Ascidian Eudistoma toealensis and Its Predatory Flatworm Pseudoceros sp. J. Nat. Prod. 1999, 62, 959-962. [CrossRef]

42. Jares-Erijman, E.A.; Sakai, R.; Rinehart, K.L. Crambescidins: New antiviral and cytotoxic compounds from the sponge Crambe crambe. J. Org. Chem. 1991, 56, 5712-5715. [CrossRef]

43. Olszewski, A.; Sato, K.; Aron, Z.D.; Cohen, F.; Harris, A.; McDougall, B.R.; Robinson, W.E.; Overman, L.E.; Weiss, G.A. Guanidine alkaloid analogs as inhibitors of HIV-1 Nef interactions with p53, actin, and p56lck. Proc. Natl. Acad. Sci. USA 2004, 101, 14079-14084. [CrossRef]

44. Mayer, A.M.S.; Rodríguez, A.D.; Taglialatela-Scafati, O.; Fusetani, N. Marine Pharmacology in 2012-2013: Marine Compounds with Antibacterial, Antidiabetic, Antifungal, Anti-Inflammatory, Antiprotozoal, Antituberculosis, and Antiviral Activities; Affecting the Immune and Nervous Systems, and Other Miscellaneous Mechanisms of Action. Mar. Drugs 2017, 15, 273.

45. Tischer, J.; Gergely, F. Anti-mitotic therapies in cancer. J. Cell Biol. 2019, 218, 10-11. [CrossRef] [PubMed]

46. Borner, C.; Monney, L. Apoptosis without caspases: An inefficient molecular guillotine? Cell Death Differ. 1999, 6, 497-507. [CrossRef] [PubMed]

47. Tamura, Y.; Chiba, Y.; Tanioka, T.; Shimizu, N.; Shinozaki, S.; Yamada, M.; Kaneki, K.; Mori, S.; Araki, A.; Ito, H.; et al. NO donor induces Nec-1-inhibitable, but RIP1-independent, necrotic cell death in pancreatic $\beta$-cells. FEBS Lett. 2011, 585, 3058-3064. [CrossRef] [PubMed]

48. Edrada-Ebel, R.; Jaspars, M. The 9th European Conference on Marine Natural Products. Mar. Drugs 2015, 13, 7150-7249. [CrossRef] [PubMed]

49. Legrave, N.; Hamrouni-Buonomo, S.; Dufies, M.; Guérineau, V.; Vacelet, J.; Auberger, P.; Amade, P.; Mehiri, M. Nepheliosyne B, a New Polyacetylenic Acid from the New Caledonian Marine Sponge Niphates sp. Mar. Drugs 2013, 11, 2282-2292. [CrossRef]

50. Stierlin, E.; Azoulay, S.; Massi, L.; Fernandez, X.; Michel, T. Cosmetic potentials of Prunus domestica L. leaves. J. Sci. Food Agric. 2018, 98, 726-736. [CrossRef]

51. Zegzouti, H.; Zdanovskaia, M.; Hsiao, K.; Goueli, S.A. ADP-Glo: A Bioluminescent and Homogeneous ADP Monitoring Assay for Kinases. ASSAY Drug Dev. Technol. 2009, 7, 560-572. [CrossRef]

52. Raynal, P.; Pollard, H.B. Annexins: The problem of assessing the biological role for a gene family of multifunctional calcium- and phospholipid-binding proteins. Biochim. et Biophys. Acta (BBA)—Rev. Biomembr. 1994, 1197, 63-93. [CrossRef]

53. Vermes, I.; Haanen, C.; Steffens-Nakken, H.; Reutellingsperger, C. A novel assay for apoptosis Flow cytometric detection of phosphatidylserine expression on early apoptotic cells using fluorescein labelled Annexin, V. J. Immunol. Methods 1995, 184, 39-51. [CrossRef] 
54. Nicoletti, I.; Migliorati, G.; Pagliacci, M.C.; Grignani, F.; Riccardi, C. A rapid and simple method for measuring thymocyte apoptosis by propidium iodide staining and flow cytometry. J. Immunol. Methods 1991, 139, 271-279. [CrossRef]

55. Manning, G.; Plowman, G.D.; Hunter, T.; Sudarsanam, S. Evolution of protein kinase signaling from yeast to man. Trends Biochem. Sci. 2002, 27, 514-520. [CrossRef]

(C) 2019 by the authors. Licensee MDPI, Basel, Switzerland. This article is an open access article distributed under the terms and conditions of the Creative Commons Attribution (CC BY) license (http://creativecommons.org/licenses/by/4.0/). 